\title{
Case Based Reasoning untuk Diagnosis Penyakit Infeksi Saluran Pernapasan Akut
}

\author{
Munazat Salmin ${ }^{l}$ \\ Program Studi Teknik Informatika, Fakultas Teknik, Universitas Pasifik Morotai \\ Jl. Siswa Darame Kec. Morotai Selatan Kab. Pulau Morotai \\ E-mail : ${ }^{1}$ munazatc28@gmail.com
}

Abstract -- One of the computerized system is highly developed in this century is the system of Case Based Reasoning (CBR) where the system is able to complete a new case based on experience or previous cases. CBR provides solutions based on the degree of similarity in the old case with a new case. The system built in this research is the CBR system for diagnosing respiratory diseases by using the Minkowski distance as the similarity calculation. Calculation of accuracy in this study using a K-fold cross validation by using $k=5$ and $k=7$. Testing with $k=5$, the best results are $\geq 60 \%$ threshold with $99.29 \%$ accuracy while using the lowest threshold value of $\geq 80 \%$ with accuracy is $88.57 \%$. Testing with $k=7$, the best results are $\geq 60 \%$ threshold with accuracy 99.29\%, while the lowest was using a threshold value of $\geq 80 \%$ with accuracy is $89.29 \%$.

Keyword : Case-based reasoning, minkowski distance, acute respiratory tract infections.

Abstrak - Salah satu sitem komputerisasi yang sangat berkembang pada abad ini adalah sistem Case Based Reasoning (CBR) dimana sistem ini dapat menyelesaikan kasus baru berdasarkan pengalaman atau kasus sebelumnya. CBR memberikan solusi berdasarkan tingkat kemiripan kasus lama dengan kasus baru. Sistem yang dibangun dalam penelitian ini adalah sistem CBR untuk melakukan diagnosis penyakit ISPA dengan menggunakan metode minkowski distance sebagai perhitungan similaritas. Perhitungan akurasi pada penelitian ini menggunakan $K$-fold cross validation dengan menggunakan $k=5$ dan $k=7$. Pengujian dengan $k=5$, hasil terbaik yaitu threshold $\geq 60 \%$ dengan akurasinya $99,29 \%$ sedangkan yang terendah menggunakan threshold $\geq 80 \%$ dengan nilai akurasinya adalah $88,57 \%$. Pengujian dengan $\mathrm{k}=7$, hasil terbaik yaitu threshold $\geq 60 \%$ dengan akurasinya $99,29 \%$, sedangkan yang terendah menggunakan threshold $\geq 80 \%$ dengan nilai akurasinya adalah $89,29 \%$.

Kata kunci-Case-based reasoning, minkowski distance, infeksi saluran pernapasan akut.

\section{PENDAHULUAN}

Infeksi saluran pernapasan akut merupakan masalah kesehatan yang ada di negara berkembang dan negara maju. Penyakit infeksi saluran pernapasan akut merupakan penyakit yang sebagian besar (90\%) disebabakan karena infeksi virus yang tidak membutuhkan anti biotika dalam penanganannya. Berdasarkan data Dinkes D.I.Y (2013), laporan STP Rumah Sakit rawat jalan dilakukan pengolahan dengan hasil yang tidak jauh berbeda dari laporan di tingkat puskesmas untuk Daerah Istimewa Yogyakarta yaitu dari 10 besar penyakit didominasi oleh penyakit infeksi saluran pernapasan akut, penyakit influenza yang terbanyak yaitu 39.675 jiwa dan Pneumonia 8.865 jiwa [1].

Kasus- kasus dapat diperoleh dari pengalaman seseorang atau pengalaman seorang pakar dibidangnya dapat diimplementasikan dengan membuat sebuah system terkomputerisasi. Salah satu kemampuan manusia yang coba ditiru oleh para ahli adalah kemampuan dalam menyelesaikan masalah berdasarkan pengalaman-pengalaman sebelumnya. Para ahli komputer membuat sistem yang disebut dengan case based reasoning (CBR) [2].

Salah satu metode pada CBR yang digunakan dalam mengukur kimiripan antara kasus tersebut adalah minkowski distance. Metode minkowski distance pernah digunakan dengan membandingkan tiga metode untuk perhitungan similarity yaitu metode nearest neighbor similarity, minkowski distance dan euclidean distance. Hasil pengujian untuk diagnosis awal penyakit jantung menunjukan bahwa sistem mampu mengenali penyakit jantung dengan perhitungan tingkat akurasi $100 \%$ dengan menggunakan metode minkowski distance [3]. Metode weighted minkowski distance juga pernah digunakan untuk mengiplementasikan CBR dengan target case diatas 80, sistem dapat mengenali penyakit-penyakit cardiovascular (I21) secara benar (sensitifitas) sebesar $100 \%$, mengenali penyakit bukan I21 (spesifitas) 
sebesar 83,33\%, dengan tingkat akurasi sebesar $95,83 \%$ serta tingkat kesalahan atau (error rate) sebesar 4,17\% [4]. Berdasarkan uraian beberapa penelitian diatas maka maka peneliti melakukan penelitian tentang diagnosis penyakit ISPA yang di implementasikan dalam CBR dengan minkowski distance. Kasus-kasus yang mirip di retrieval dengan manual sangat tidak efisien dalam hal waktu maka dibutuhkan sebuah sistem CBR yang berbasis komputer. Dengan sistem terkomputerisasi ini dapat membantu tenaga medis agar bisa diagnosis penyakit infeksi saluran pernapasan akut secara cepat dan akurasinya tepat.

\section{METODE PENELITIAN}

\section{Case Based Reasoning}

Istilah case based reasoning (CBR) mulai banyak dikenal diberbagai bidang baik dalam bidang teknologi informasi dan ilmu komputer. CBR adalah pendekatan pemecahan masalah berdasarkan membandingkan mengenai masalah yang baru terjadi dengan pengalaman masa lalu atau kasus sebelumnya [5].

\section{Pengukuran Similaritas}

Ketika ada permasalahan baru yang muncul maka langkah pertama adalah mengambil kasus-kasus yang disimpan di dalam basis kasus dengan cara melakukan pengukuran similaritas. Pengukuran similaritas akan menghasilkan nilai yang menentukan tentang ada atau tidak kemiripan antara kasus yang baru dengan kasus-kasus yang ada dalam basis kasus dengan membandingkan fitur yang ada pada kasus baru dengan sejenis yang ada pada basis kasus. Pengukuran similaritas yang digunakan dalam penelitian ini mencakup :

a. Similaritas Lokal

Similaritas lokal menunjukan kesamaan antara atribut permasalahan baru terhadap atribut yang tersimpan dalam basis kasus.Persamaan (1) untuk menghitung similaritas lokal untuk tipe data numerik [6].

$$
f\left(S_{k}, T_{k}\right)=1-\frac{\left|S_{k}-T_{k}\right|}{R}
$$

Dimana, $S_{k}, T_{k}$ adalah nilai fitur yang ingin dibandingkan dan $R$ adalah range nilai untuk fitur tersebut.

Untuk tipe data Boolean, berlaku fungsi similaritas lokal [7].Menggunakan persamaan (2).

$$
\begin{aligned}
f\left(S_{k}, T_{k}\right)= & \left\{\begin{array}{c}
1 \text { jika } S_{k}=T_{k} \\
0 \text { lainnya }
\end{array} \text { untuk } S_{k}, T_{k}\right. \\
& \{\text { benar,salah }\}
\end{aligned}
$$

b. Pengkuran Tingkat Keyakinan

Tingkat keyakinan adalah pencerminanan tingkat kepastian yang diinginkan oleh pengukur setelah memutuskan tidak akan melakukan pengukuran yang sangat banyak [2]. Persamaan (3) untuk menghitung tingkat keyakinan bahwa suatu permasalahan baru $(T)$ merupakan bagian dari sebuah kelas dalam basis kasus $(S)$ [2].

$$
P_{k}\left(S_{k}, T_{k}\right)=P k(S k) * \frac{J\left(S_{k}, T_{k}\right)}{J\left(T_{k}\right)}
$$

Dimana, $P_{k}\left(S_{k}, T_{k}\right)$ adalah normalisasi similaritas dengan tingkat keyakinan, $P_{k}\left(S_{k}\right)$ adalah presentase tingkat keyakinan dalam suatu kasus ke- $k$ dalam source case, $J\left(S_{k}, T_{k}\right)$ adalah total fitur dalam target case yang muncul pada source case, dan $J\left(T_{k}\right)$ adalah total fitur dalam target case.

c. Similaritas Global

Dalam penelitian ini metode yang digunakan untuk mengitung kemiripan kasus baru dengan kasus lama yaitu metode minkowski distance. Minkowski distance merupakan metode perhitungan kemiripan berdasarkan jarak. Metode ini juga merupakan generalisasi dari metode distance yang lain. Jika Jika $\mathrm{r}=1$ dikenal dengan manhattan/city block distance, jika $\mathrm{r}=2$ dikenal dengan euclidean distance dan jika $\mathrm{r}=$ infinity (tak hingga) dikenal dengan chebyshev distance [8]. Minkowski distance dengan pembobotan ditunjukan menggunakan persamaan (4) [9].

$$
\operatorname{Sim}(S, T)=\left[\frac{\sum_{k=1}^{n}\left(w_{k}, p(s)\right)^{r} *\left|f_{k}\left(S_{k}, T_{k}\right)^{r}\right|}{\sum_{k=1}^{n}\left(w_{k}, p(s)\right)^{r}}\right]^{1 / r}
$$

Dimana, $\operatorname{Sim}(S, T)$ adalah similaritas global antara source case ( $S$ ) dan target case $(T), n$ adalah banyak fitur, $r$ adalah faktor minkowski (nilai $r=3$ ), $w_{k}, p_{s}$ adalah nilai bobot fitur ke- $k$ pada source case, $f_{k}\left(S_{k}, T_{k}\right)$ adalah fungsi similaritas lokal ke- $k$ pada penyakit dari source case dan target case, $S_{k}$ adalah atribut ke- $k$ pada source case, dan $T_{k}$ adalah atribut ke- $k$ pada target case.

Nilai $r$ adalah bilangan positif $\geq 1$, (antara 1 sampai dengan tak terhingga). Pada penelitian sebelumnya yang menggunakan $r=3$ dengan hasil akurasi maksimum.

Persamaan (4) dimodifikasi dengan menambah faktor tingkat keyakinan dari persamaan (3) kedalam perhitungan similaritas kasus sebagaimana ditunjukan oleh persamaan (5).

$$
\begin{gathered}
\operatorname{Sim}(S, T)=\left[\frac{\sum_{k=1}^{n}\left(w_{k}, p(s)\right)^{r} *\left|f_{k}\left(S_{k}, T_{k}\right)^{r}\right|}{\sum_{k=1}^{n}\left(w_{k}, p(s)\right)^{r}}\right] 1 / r * P_{k}\left(S_{k}\right) * \\
\frac{J\left(S_{k}, T_{k}\right)}{J\left(T_{k}\right)}
\end{gathered}
$$

Dimana $\operatorname{Sim}(S, T)$ adalah Similaritas global antara source case $(S)$ dan target case $(T), n$ adalah banyak fitur, $r$ adalah Faktor minkowski (nilai $r=3$ ), $w_{k}, p_{s}$ adalah nilai bobot fitur ke- $k$ pada source case, $f_{k}\left(S_{k}, T_{k}\right)$ adalah kesamaan fitur ke-k pada penyakit dari source case dan target case atau fungsi similaritas lokal, $S_{i}$ adalah Fitur ke- $k$ pada souce case, $T i$ adalah fitur ke- $k$ pada target case, $P_{k}$ 
$\left(S_{k}\right)$ adalah presentase tingkat keyakinan dalam suatu kasus ke- $k$ dalam source case, $J\left(S_{k}, T_{k}\right)$ adalah total fitur dalam target case yang muncul pada source case, dan $J\left(T_{k}\right)$ adalah total fitur dalam target case.

\section{Pengujian Sistem}

Akurasi yaitu tingkat kedekatan pengukuran kuantitas terhadap nilai yang sebenarnya. Pengukuran akurasi dilakukan dengan membandingkan jumlah diagnosis benar oleh sistem dengan jumlah data uji. Untuk pengukuran akurasi pada penelitian ini digunakan dengan menggunakan K-fold cross validation. Perbandingan dapat dituliskan dalam bentuk persamaan (6) [10].

$$
\mathrm{P}=\frac{C}{N} \times 100 \%
$$

Diagram Konteks

Diagram konteks merupakan level tertinggi dari DFD yang terdiri dari suatu proses yang menggambarkan suatu sistem terkait dengan dokumen output dan input serta entitas yang berhubungan dengan sistem. Sistem CBR diagnosis penyakit ISPA ini berhubungan dengan dua entitas, yaitu pakar dan paramedis. Diagram konteks pada sistem CBR diagnosis penyakit ISPA terlihat pada Gambar1.

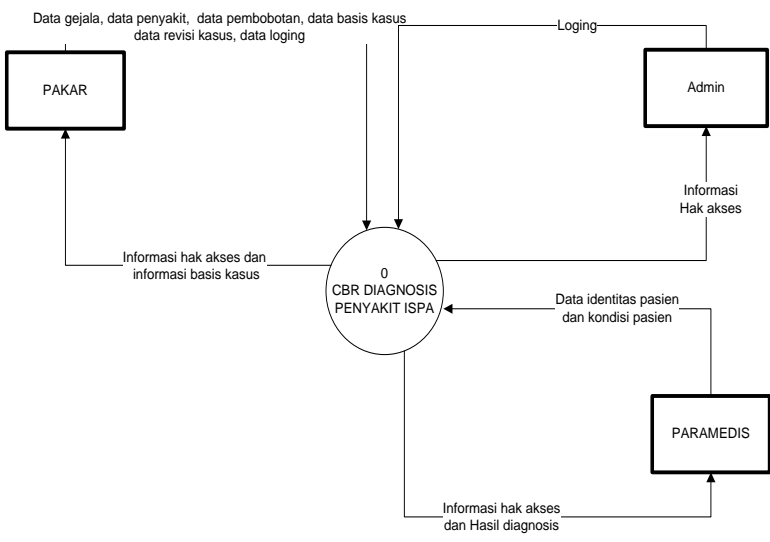

Gambar 1 Diagram konteks sistem CBR untuk diagnosis penyakit ISPA

Keterangan :

1. Administrator merupakan user yang memiliki level dalam pengaksesan sistem dan mengelola data user. Administrator harus melakukan login terlebih dahulu untuk menggunakan sistem.

2. Untuk masuk kesistem pakar melakukan loging terlebih dahulu. Pakar merupakan user yang memiliki hak akses terbatas. Pakar melakukan input data penyakit, input data gejala, input data faktor resiko, input data bobot, input data penyakit, input basis kasus, dan revisi kasus.

3. Untuk masuk kesistem paramedis melakukan loging terlebih dahulu. Selain dari pakar, paramedis juga merupakan user yang memiliki hak akses terbatas. Paramedis melakukan diagnosis dan menyimpan permasalahan baru.

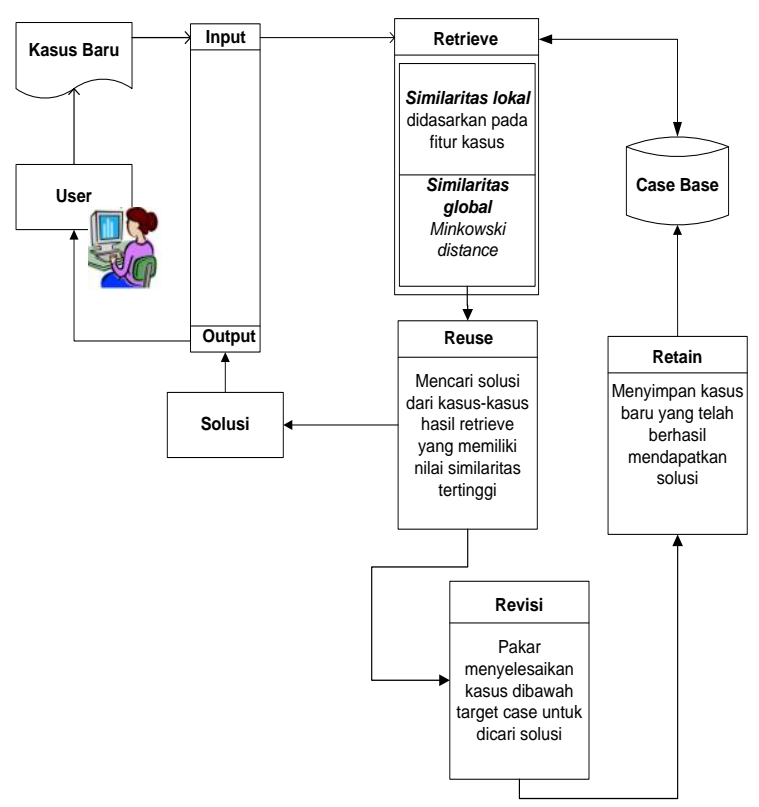

Gambar 2. Proses sistem CBR untuk diagnosis penyakit ISPA

\section{HASIL DAN PEMBAHASAN}

Proses Diagnosis

Berikut contoh perhitungan dengan menggunakan similaritas lokal dan global.

Tabel 1 Contoh data kasus baru

\begin{tabular}{|c|l|l|}
\hline No & \multicolumn{2}{|c|}{ Data Kasus Baru } \\
\hline 1 & Data Pasien & 18 tahun \\
\hline 2 & Uenis_Kelamin & Wanita \\
\hline & Gejala & \\
\hline 1 & G01 & Demam \\
\hline 2 & G02 & Nyeri telan \\
\hline 3 & G03 & Nyeri tenggorokan \\
\hline 4 & G08 & Batuk \\
\hline 5 & G10 & Malaise \\
\hline 7 & G16 & Dahak \\
\hline 8 & G18 & Suara serak \\
\hline 8 & G21 & Muntah \\
\hline 9 & G22 & Pusing \\
\hline & Faktor Resiko & Infeksi \\
\hline 1 & R03 & Contoh basis kasus \\
\hline
\end{tabular}

Tabel 2. Contoh basis kasus dalam bentuk frame

Proses diagnosis dilakukan dengan menghitung similaritas lokal yang dibagi menjadi 2 (dua) bagian yaitu usia, jenis kelamin, gejala dan faktor resiko. Perhitungan usia menggunakan persamaan (1), 


\begin{tabular}{|c|c|c|c|c|c|}
\hline \multicolumn{3}{|c|}{ Data Kasus C001 } & \multicolumn{3}{|c|}{ Data Kasus C002 } \\
\hline $\begin{array}{l}\text { Data } \\
\text { Pasien }\end{array}$ & Ket & Bobot & Data Pasien & Ket & Bobot \\
\hline Usia & 16 & 4 & Usia & 23 & 4 \\
\hline $\begin{array}{l}\text { Jenis } \\
\text { kelamin }\end{array}$ & Wanita & 3 & $\begin{array}{l}\text { Jenis } \\
\text { kelamin }\end{array}$ & Pria & 3 \\
\hline Gejala & & & Gejala & & \\
\hline G01 & Demam & 3 & G01 & Demam & 3 \\
\hline G02 & Nyeri telan & 7 & G02 & Nyeri telan & 7 \\
\hline G03 & $\begin{array}{l}\text { Nyeri } \\
\text { tenggorokan }\end{array}$ & 5 & G03 & $\begin{array}{l}\text { Nyeri } \\
\text { tenggorokan }\end{array}$ & 5 \\
\hline G05 & Pilek & 2 & G04 & Sakit kepala & 3 \\
\hline G08 & Batuk & 2 & G08 & Batuk & 2 \\
\hline G10 & Malaise & 3 & G10 & Malaise & 3 \\
\hline G16 & Dahak & 4 & G11 & Anoreksia & 2 \\
\hline G18 & Suara serak & 2 & G16 & Dahak & 4 \\
\hline & & & G22 & Pusing & 2 \\
\hline $\begin{array}{l}\text { Faktor } \\
\text { Resiko }\end{array}$ & & & $\begin{array}{l}\text { Faktor } \\
\text { Resiko }\end{array}$ & & \\
\hline R03 & Infeksi & 3 & R03 & Infeksi & 3 \\
\hline R05 & $\begin{array}{l}\text { Riwayat } \\
\text { penyakit }\end{array}$ & 3 & & & \\
\hline $\begin{array}{l}\text { Jenis } \\
\text { Penyakit }\end{array}$ & $\mathrm{J} 0$ & & $\begin{array}{l}\text { Jenis } \\
\text { Penyakit }\end{array}$ & $\overline{\mathrm{J} 02}$ & \\
\hline $\begin{array}{l}\text { Tingkat } \\
\text { Keyakina } \\
\text { n Pakar }\end{array}$ & 100 & & $\begin{array}{l}\text { Tingkat } \\
\text { Keyakinan } \\
\text { Pakar }\end{array}$ & 100 & \\
\hline
\end{tabular}

sedangkan kedekatan jenis kelamin, gejala dan faktor resiko menggunakan persamaan (2).

a. Hitung dengan menggunakan rumus similaritas lokal

Similaritas lokal adalah menghitung kemiripan antar fitur-fitur antara basis kasus denga kasus baru. Perhtungnnya menggunakan pada persamaan (1) dan (2).

1. Kemiripan kasus baru (target case) dengan kasus lama (source case) pada basis kasus (C001)

a. Kedekatan usia

$f(s, t)=1-\frac{|18-16|}{86-1}=1-\frac{2}{85}=1-0.024=0,976$

b. Jenis kelamin $=1$ karena jenis kelamin pada kasus baru sama dengan kasus lama (pada basis kasus).

c. Kedekatan gejala :

1. Gejala G01, G02, G03, G08, G10, G16, G18 bernilai 1 karena gejala tersebut ada pada kasus lama.

2. Gejala G05 bernilai 0 karena gejala tersebut muncul di kasus lama tetapi tidak ada pada kasus baru.

3. Gejala G21, G22 bernilai 0 karena gejala tersebut muncul dikasus baru tetapi tidak ada pada kasus lama.

d. Kedekatan faktor resiko :

1. Resiko R03 bernilai 1 karena resiko pada kasus baru sama dengan kasus lama.

2. Resiko R05 bernilai 0 karena resiko pada kasus lama yang tidak ada pada kasus baru.

2. Kemiripan kasus baru (target case) dengan kasus lama (source case) pada basis kasus (C002).

a. Kedekatan usia

$$
f(s, t)=1-\frac{|23-18|}{86-1}=1-\frac{5}{85}=1-0.058=0,942
$$

b. Jenis kelamin $=0$ karena jenis kelamin pada kasus baru tidak sama dengan kasus lama. c. Kedekatan gejala:

1. Gejala G01, G02, G03, G08, G10, G16, G22 bernilai 1 karena gejala tersebut ada pada kasus lama.

2. Gejala G04, G11 bernilai 0 karena gejala tersebut muncul di kasus lama tetapi tidak ada pada kasus baru.

3. Gejala G18, G21 bernilai 0 karena gejala tersebut muncul dikasus lama tetapi tidak ada pada kasus lama.

d. Kedekatan faktor resiko R03 bernilai 1 karena resiko pada kasus baru sama dengan kasus lama.

b. Hitung dengan menggunakan rumus similaritas global

Perhitungan similaritas adalah mengukur kemiripan antar kasus menggunakan metode minkowski distance similarity. Menghitung similaritas global menggunakan persamaan (5).

1. Kemiripan kasus baru (target case) dengan kasus lama (source case) (C001).

Perhitungan dengan menggunakan metode minkowski distance

$\left[\begin{array}{c}(0,976.4)^{3}+(1.3)^{3}+(1.6)^{3}+(1.10)^{3}+(1.8)^{3}+ \\ (0.3)^{3}+(1.6)^{3}+(1.4)^{3}+(1.5)^{3}+(1.4)^{3}+ \\ \frac{(0.2)^{3}+(0.3)^{3}+(1.4)^{3}+(0.5)^{3}}{4^{3}+3^{3}+6^{3}+10+8^{3}+3^{3}+6^{3}+4^{3}+} \\ 5^{3}+4^{3}+2^{3}+3^{3}+4^{3}+5^{3}\end{array}\right] 1 / 3 \times \frac{10}{12} \times 100$

$=\left[\frac{59,50+27+216+1000+512+216+64+125+64+64}{64+27+216+1000+512+27+216+64+125+64+8+27+64+125}\right]^{1 / 3} \times$ $83,33 \%$

$=\left[\frac{2347,5}{2539}\right]^{1 / 3} * 83,33=0,974 \times 83,33 \%=81,18 \%$.

2. Kemiripan kasus baru (target case) dengan kasus lama (source case) (C002).

Perhitungan dengan menggunakan metode minkowski distance

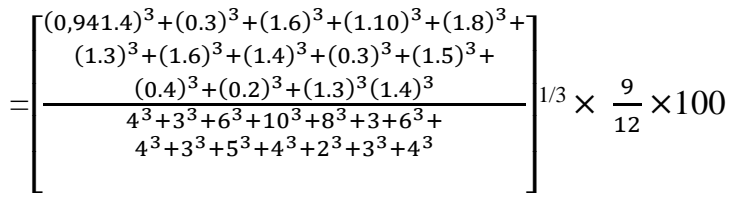

$=\left[\frac{53,36+216+1000+512+216+64+125+27+64}{64+27+216+1000+512+27+216+64+27+125+64+8+27+64}\right] 1 /$ ${ }^{3} \times 75 \%$

$=\left[\frac{2277,33}{2441}\right]^{1 / 3} * 75 \%=0,977 \times 75 \%=73,29 \%$

Dari hasil perhitungan kasus baru terhadap basis kasus pada basis kasus C001, didapatkan nilai similaritas tertinggi dengan menggunakan metode minkowski distance adalah $81,18 \%$. nilai similaritasnya diatas threshold sehingga tidak dilakukan revisi kasus. 
Hasil perhitungan kasus baru terhadap basis kasus pada basis kasus C002 didapatkan nilai similaritas tertinggi dengan menggunakan metode minkowski distance adalah $73,29 \%$.

Berdasarkan perhitungan similaritas permasalahan baru terhadap basis kasus yaitu basis kasus C001 dan C002 dimana nilai similaritas tertingi adalah kasus C001 dibandingkan kasus C002, jadi kesimpulannya bahwa kasus yang paling mirip adalah kasus C001 dengan similaritasnya adalah $81,18 \%$. Kasus C001 tersebut akan dipromosikan untuk menjadi solusi dari permasalahan baru (target case).

\section{Pembahasan Hasil Pengujian}

Pengujian ini menggunakan metode K-fold cross validation, dimana total data kasus penyakit ispa adalah 140 kasus dibagi kedalam 5 subset $(\mathrm{k}=5)$ dan 7 subset $(\mathrm{k}=7)$ dengan rincian masing-masing subset terdapat 28 data kasus dan 20 data kasus. Pembagian kasus kedalam subset dilakukan secara random dimana semua jenis penyakit terisi pada setiap subset secara merata. Untuk pengukuran kinerja akurasi sistem yang dibangun dalam penelitian ini menggunakan persamaan (6).

Tabel 3 Rata-rata akurasi untuk k= 5

\begin{tabular}{|l|c|c|c|c|c|c|}
\hline $\begin{array}{l}\text { Pengujian } \\
\text { ke- }\end{array}$ & 1 & 2 & 3 & 4 & 5 & $\begin{array}{c}\text { Rata-rata } \\
\text { akurasi }\end{array}$ \\
\hline $\begin{array}{l}\text { threshold } \\
\geq 60 \%\end{array}$ & $100 \%$ & $100 \%$ & $\begin{array}{c}96,43 \\
\%\end{array}$ & $100 \%$ & $100 \%$ & $99,29 \%$ \\
\hline $\begin{array}{l}\text { threshold } \\
\geq 65 \%\end{array}$ & $100 \%$ & $100 \%$ & $\begin{array}{c}96,43 \\
\%\end{array}$ & $100 \%$ & $96,43 \%$ & $98,57 \%$ \\
\hline $\begin{array}{l}\text { threshold } \geq \\
70 \%\end{array}$ & $100 \%$ & $\begin{array}{c}96,43 \\
\%\end{array}$ & $\begin{array}{c}89,29 \\
\%\end{array}$ & $100 \%$ & $96,43 \%$ & $96,43 \%$ \\
\hline $\begin{array}{l}\text { threshold } \\
\geq 75 \%\end{array}$ & $96,43 \%$ & $\begin{array}{c}89,29 \\
\%\end{array}$ & $\begin{array}{c}89,29 \\
\%\end{array}$ & $100 \%$ & $96,43 \%$ & $94,29 \%$ \\
\hline $\begin{array}{l}\text { threshold } \\
\geq 80 \%\end{array}$ & $92,86 \%$ & $\begin{array}{c}85,71 \\
\%\end{array}$ & $\begin{array}{c}82,14 \\
\%\end{array}$ & $\begin{array}{c}89,29 \\
\%\end{array}$ & $92,86 \%$ & $88,57 \%$ \\
\hline
\end{tabular}

\section{Hasil rata-rata akurasi untuk $\mathrm{k}=\mathbf{5}$}

Pengujian dengan $\mathrm{k}=5$ menggunakan threshold $\geq 60 \%$ akurasinya adalah $99,29 \%$, pengujian dengan menggunakan threshold $\geq 65 \%$ akurasinya adalah $98,57 \%$, pengujian dengan menggunakan threshold $\geq 70 \%$ akurasinya adalah $96,43 \%$, pengujian dengan menggunakan threshold $\geq 75 \%$ akurasinya adalah $94,29 \%$, pengujian dengan menggunakan threshold $\geq 80 \%$ akurasinya adalah $88,57 \%$. Untuk lebih jelas tentang detail pengujian dapat dilihat pada Tabel 3 .

\section{Tabel 4 Rata-rata akurasi untuk k=7}

\section{Hasil rata-rata akurasi untuk $k=7$}

\begin{tabular}{|l|c|c|c|c|c|c|c|c|}
\hline $\begin{array}{l}\text { Pengujian } \\
\text { ke- }\end{array}$ & $1(\%)$ & $\begin{array}{c}2 \\
(\%)\end{array}$ & $3(\%)$ & $4(\%)$ & $5(\%)$ & $6(\%)$ & $7(\%)$ & $\begin{array}{c}\text { Rata-rata } \\
\text { akurasi }\end{array}$ \\
\hline $\begin{array}{l}\text { threshold } \\
\geq 60 \%\end{array}$ & 100 & 100 & 100 & 95 & 100 & 100 & 100 & $99,29 \%$ \\
\hline $\begin{array}{l}\text { threshold } \\
\geq 65 \%\end{array}$ & 100 & 100 & 100 & 95 & 100 & 100 & 95 & $98,57 \%$ \\
\hline $\begin{array}{l}\text { threshold } \\
\geq 70 \%\end{array}$ & 100 & 100 & 90 & 90 & 100 & 100 & 95 & $96,43 \%$ \\
\hline $\begin{array}{l}\text { threshold } \\
\geq 75 \%\end{array}$ & 100 & 100 & 85 & 85 & 100 & 95 & 95 & $94,29 \%$ \\
\hline $\begin{array}{c}\text { threshold } \\
\geq 80 \%\end{array}$ & 90 & 90 & 85 & 80 & 95 & 90 & 95 & 89,29 \\
\hline
\end{tabular}

threshold $\geq 60 \%$ akurasinya adalah $99,29 \%$, pengujian dengan menggunakan threshold $\geq 65 \%$ akurasinya adalah $98,57 \%$, pengujian dengan menggunakan threshold $\geq 70 \%$ akurasinya adalah $96,43 \%$, pengujian dengan menggunakan threshold $\geq 75 \%$ akurasinya adalah $94,29 \%$, pengujian dengan menggunakan threshold $\geq 80 \%$ akurasinya adalah $89,29 \%$. Untuk lebih jelas tentang detail pengujan dilihat pada Tabel 4 .

\section{SIMPULAN}

Berdasarkan penelitian dan hasil pengujian yang telah dilakukan, maka dapat disimpulkan bahwa:

1. Penelitan ini memberikan hasil sistem CBR untuk dagnosis penyakit ISPA dengan memperhitungkan kedekatan antara kasus baru (new case) dan kasus lama (old case) berdasarkan fitur usia, jenis kelamin, fitur gejala dan fitur faktor resiko yang telah diberi bobot dan tingkat keyakinan pakar.

2. Hasil pengujian dengan $\mathrm{k}=5$ (5-fold) dari data yang didapatkan pada rekam medik pasien dengan masing-masing subset terisi 28 data, hasil terbaik yaitu dengan menggunakan threshold $\geq 60 \%$ dengan akurasinya $99,29 \%$ sedangkan yang terendah menggunakan threshold $\geq 80 \%$ dengan nilai akurasinya adalah $88,57 \%$. Pengujian dengan $\mathrm{k}=7$ (7-fold) dari data yang didapatkan pada rekam medik pasien dengan masing-masing subset terisi 20 data, hasil terbaik yaitu dengan menggunakan threshold $\geq 60 \%$ dengan akurasinya 99,29\% sedangkan yang terendah menggunakan threshold $\geq 80 \%$ dengan nilai akurasinya adalah $89,29 \%$.

3. Pengujian menggunakan threshold $<60 \%$ tidak dilakukan karena pada basis kasus terdapat penyakit tertentu memiliki sedikit fitur sehingga inputan usia dan jenis kelamin pasien sudah bisa mendiagnosis suatu penyakit.

\section{DAFTAR PUSTAKA}

[1] Dinkes D.I.Y., 2013. Profil Kesehatan D.I.Y, Yogyakarta.

http://www.depkes.go.id/resources/download/pro fil/PROFIL_KES_PROVINSI_2012/14_Profil_ Kes.Prov.DIYogyakarta_2012.pdf diakses tgl 17 Januari 2016. 
[2] Pal, S. K. dan Shiu, S. C. K, 2004, Foundation of Soft Case-Based Reasoning, John Willey and Sons, Inc., Hoboken, New Jersey.

[3] Wahyudi E., 2015, Case Based Reasoning Untuk Diagnosis Penyakit Jantung, Tesis, Program Pasca Sarajana Ilmu Komputer, UGM, Yogyakarta.

[4] Faizal, E., 2013, Case-Based Reasoning Untuk Diagnosis Penyakit Cardiovascular dengan Metode Weighted Minkowski, Tesis, Program Pasca Sarajana Ilmu Komputer, UGM, Yogyakarta.

[5] Katedee, S.,Sanrach, C., and Thesawadwong, T., 2010, Case-Based Reasoning System for Histopathology Diagnosis., Thailand.

[6] Jha, M.K., Pakhira, D., dan Chakraborty, B., 2013, Diabetes Detection and Care Applying CBR Techniques, IJSCE, 6, 2, 132-137.

[7] Nurdiansyah, Y., dan Hartati, S., 2014, CaseBased Reasoning untuk Pendukung Diagnosis Gangguan pada Anak Autis, Thesis, Prodi S2/S3 Ilmu Komputer, Universitas Gadjah Mada, Yogyakarta.

[8] Mergio, J.M., dan Casanovas, M., 2008, The Induced Minkowski Ordered Weighted Averaging Distance Operator, ESTYLF08, Cuencas Mineras (Mieres-Langreo), Congreso Espanol sobre Tecnologiasy Logica Fuzzy, pp 3541.

[9] Nunez, H., Marre, M.S., Cortes, U., Comas, J., Martinez, M., Roda, I.R., dan Poch, M., 2004, A comparative study on the use of similarity measures in case based reasoning to improve the classification of environmental system situations, Original Research Article, Environmental Modelling \& Software, Volume 19, Issue 9, pp 809-819.

[10] Bramer, M., 2007, Principles of Data Mining, Springer-Verlag, London. 